\title{
A case of insulin-like growth factor 2- producing gastrointestinal stromal tumor with severe hypoglycemia
}

Haruka Yamasaki ${ }^{1 \dagger}$, Ayako Itawaki $^{2 \dagger}$, Miwa Morita ${ }^{1 *}$ (D) Hitomi Miyake ${ }^{1}$, Masahiro Yamamoto ${ }^{1}$, Hiroki Sonoyama ${ }^{2}$,

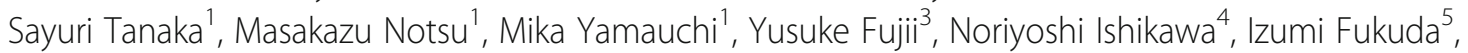
Shunji Ishihara ${ }^{2}$ and Keizo Kanasaki ${ }^{1,6}$

\begin{abstract}
Background: Non-islet cell tumor hypoglycemia $(\mathrm{NICTH})$ is a rare paraneoplastic syndrome that secretes incompletely processed high molecular weight insulin growth factor 2 (big-IGF2), which results in stimulation of the insulin receptor and subsequently induces hypoglycemia. Gastrointestinal stromal tumor (GIST) is a common intestinal mesenchymal neoplasm of the gastrointestinal tract. The most frequent site of GIST is the stomach; NICTH induced by IGF2-producing stomach GISTs is rare.

Case presentation: An 84-year-old man was admitted to the hospital due to impaired consciousness (JCS II-10) in the morning. At the time of admission, his serum glucose was $44 \mathrm{mg} / \mathrm{dL}$; his consciousness was restored with $20 \mathrm{ml}$ of $50 \%$ glucose. To avoid hypoglycemia, a continuous intravenous infusion of glucose as well as dietary intervention was required. At the time of hypoglycemia, the levels of insulin and C-peptide were suppressed. Additionally, IGF1 levels were below the normal range. Abdominal computed tomography revealed that he had a large lobulated mass $(116 \times 70 \times 72$ $\mathrm{mm}$ ) around the gastric corpus. Pathological analysis of biopsy specimens identified disarray of spindle cells and positivity for c-kit as well as strong positivity for DOG-1. Further analysis revealed high levels of Ki-67 (Mib-1 index: 15.5\%) and mitotic index (7/5OHPF); the tumor was diagnosed as high-risk GIST, and complete surgical resection was performed. Hypoglycemia resolved immediately after tumor resection. The resected tumor specimen was positive for IGF2 staining, and big-IGF2 (11-18 kDa) was detected in preoperative serum and tumor samples; the patient was diagnosed with NICTH due to an IGF2-producing tumor.
\end{abstract}

Conclusions: NICTH is rare in GIST of the stomach; however, the large GIST could produce big-IGF2 and subsequently cause severe hypoglycemia, requiring prompt evaluation and complete tumor resection.

Keywords: NICTH, GIST, Hypoglycemia, Big-IGF2

\footnotetext{
* Correspondence: miwaota@med.shimane-u.ac.jp

${ }^{\dagger}$ Haruka Yamasaki and Ayako Itawaki contributed equally to this work.

'Department of Internal Medicine 1, Shimane University Faculty of Medicine,

89-1, Enya-cho, Izumo, Shimane 693-8501, Japan

Full list of author information is available at the end of the article
}

(C) The Author(s). 2020 Open Access This article is licensed under a Creative Commons Attribution 4.0 International License, which permits use, sharing, adaptation, distribution and reproduction in any medium or format, as long as you give appropriate credit to the original author(s) and the source, provide a link to the Creative Commons licence, and indicate if changes were made. The images or other third party material in this article are included in the article's Creative Commons licence, unless indicated otherwise in a credit line to the material. If material is not included in the article's Creative Commons licence and your intended use is not permitted by statutory regulation or exceeds the permitted use, you will need to obtain permission directly from the copyright holder. To view a copy of this licence, visit http://creativecommons.org/licenses/by/4.0/. The Creative Commons Public Domain Dedication waiver (http://creativecommons.org/publicdomain/zero/1.0/) applies to the data made available in this article, unless otherwise stated in a credit line to the data. 


\section{Background}

Non-islet cell tumor hypoglycemia (NICTH) is a rare paraneoplastic syndrome and has an estimated incidence of approximately one per million person-years [1]. NICTH is induced by incomplete processing of tumorsecreted high molecular weight insulin-like growth factor2 (IGF2), known as big-IGF2 or pro-IGF2E [68-88] [2] [3], which stimulates the insulin receptor and glucose utilization and subsequently induces hypoglycemia [1]. Gastrointestinal stromal tumor (GIST) is a common intestinal mesenchymal neoplasm of the gastrointestinal tract that is mainly characterized by the overexpression of receptor tyrosine kinase KIT [4] [5]. Although the most common site of GIST is the stomach (39 to $72.3 \%$ [6] [7] [8]), NICTH induced by IGF2-producing GIST of the stomach has shown to be rare [2].

Here, we report a NICTH case induced by IGF2producing primary gastric GIST.

\section{Case presentation}

An 84-year-old man was admitted to an affiliated hospital due to an impaired level of consciousness (JCS II10) in the morning.

He experienced rotatory vertigo, weakness and dizziness without any particular cause form 1 week before the admission to that hospital. Three days prior to the admission, he had fainted and fallen to the floor in the early morning. At the time of admission in that hospital, his serum glucose was $44 \mathrm{mg} / \mathrm{dL}$, and after infusion of $20 \mathrm{ml}$ of $50 \%$ glucose solution, his consciousness was restored. Blood pressure was $184 / 100 \mathrm{mmHg}$, and heart rate was $65 / \mathrm{min}$. He did not have fever, his respiratory rate was $16 / \mathrm{min}$, and $\mathrm{SpO}_{2}$ was $95 \%$ at ambient air. Other physical examinations were unremarkable. Abdominal computed tomography (CT) in the emergency unit demonstrated a large lobulated mass around the gastric corpus $\sim \phi 120 \mathrm{~mm}$. For further analysis, he was transferred to our hospital.

When transferring to our hospital, he was alert with continuous intravenous infusion of glucose. His blood pressure and heart rate were also in the normal range. He had a 2-year history of hypertension that was treated with olmesartan. He was prescribed atorvastatin, tamsulosin, and brinzolamide/timolol maleate eye drops for dyslipidemia, benign prostate hyperplasia, and glaucoma, respectively. He had taken sennoside for constipation as needed. He did not have a history of diabetes, although both his older sister and brother did. He has been followed up and monitored for intraductal papillary mucinous neoplasm (IPMN) with abdominal CT at an affiliated hospital.

After admission to our hospital, he required a continuous infusion of glucose $(4.2 \mathrm{~g} / \mathrm{h})$, a diet of $1800 \mathrm{kcal}$ per day and supplementary meals of $380 \mathrm{kcal}$ before sleep to avoid hypoglycemia. Insulin and C-peptide were suppressed at the time of hypoglycemia (Table 1). IGF1 was below the normal range $(22 \mathrm{ng} / \mathrm{mL})$ (Table 1). Hypothalamic-pituitary dysfunction was not likely the cause of his hypoglycemia (Table 1). Contrasted abdominal CT revealed a large lobulated mass of $116 \times 70 \times 72$ $\mathrm{mm}$ with central necrosis and heterogeneous enhancement around the gastric corpus (Fig. $1 \mathrm{a}$ and b). A retrospectively unclassified $\sim \phi 20 \mathrm{~mm}$ mass was found in the same location on a CT (Fig. 1c) for follow-up of regular IPMN (1.5 years ago), indicating a rapid increase in the tumor mass. NICTH was suspected due to fasting hypoglycemia, low IGF-I, suppression of insulin secretion and a large tumor.

Pathological analysis of an endoscopic ultrasoundguided fine-needle aspiration biopsy specimen identified a disarray of spindle cells and the presence of c-kit positivity as well as strong positivity for DOG-1, confirming GIST histology (Fig. 2). Further analysis revealed high levels of Ki-67 (Mib-1 index: 15.5\%) and mitotic index (7/50HPF). The tumor was diagnosed as high-risk GIST, and complete surgical resection was performed on hospital day 26. Hypoglycemia was disappeared immediately after the operation. Beginning the next day, neither glucose infusion nor supplementary meals before sleeping were required to maintain the blood glucose levels of the patient.

There was no obvious metastasis of the tumor. The resected specimen was positive for IGF2 staining (Fig. 3). Histological examination revealed the stomach-origin IGF2-producing GIST. When evaluated 1 week after the operation, the level of IGF2 was decreased (Table 2). IGF2/IGF1 remained higher; IGF1 levels were elevated to $64 \mathrm{ng} / \mathrm{mL}$ at 3 weeks after the operation. In preoperative serum and tumor samples, big-IGF2 $(11-18 \mathrm{kDa})$ was detected, and such aberrant IGF2 disappeared (Fig. 4). A final diagnosis was made as NICTH due to IGF2 production.

Since then, he has been regularly monitored by CT in our hospital, and is free from relapse of tumor or hypoglycemia for 2.5 years.

\section{Discussion and conclusions}

NICTH is a rare paraneoplastic syndrome in which a tumor secretes high molecular weight IGF2, causing hypoglycemia [1]. The major effects of IGF2, a polypeptide hormone, are growth and cell differentiation promotion in the fetal period; IGF2 also has a similar action as insulin, yet its biological activity is low (approximately $14 \%$ of that of insulin) [9].

The Igf2 gene is located on the short arm of chromosome 11 (11q15.5). The transcriptional product of the Igf2 gene is translated into a pre-pro-IGF2 polypeptide, and subsequently, posttranslational modification forms it 
Table 1 Laboratory findings on admission

\begin{tabular}{|c|c|c|c|c|c|c|}
\hline Variable & $\begin{array}{l}\text { Reference } \\
\text { Range } \\
\text { (Affiliated Hospital/ } \\
\text { This Hospital) }\end{array}$ & $\begin{array}{l}\text { On Admission } \\
\text { Affiliated } \\
\text { Hospital }\end{array}$ & $\begin{array}{l}\text { Next Day } \\
\text { Admission } \\
\text { Affiliated } \\
\text { Hospital }\end{array}$ & $\begin{array}{l}2 \text { Days after } \\
\text { Admission } \\
\text { Affiliated } \\
\text { Hospital }\end{array}$ & $\begin{array}{l}\text { On Admission } \\
\text { This Hospital }\end{array}$ & $\begin{array}{l}16 \text { Days after } \\
\text { Admission } \\
\text { This Hospital }\end{array}$ \\
\hline \multicolumn{7}{|l|}{ Blood } \\
\hline Hematocrit & $36-48 / 40.7-50.1$ (\%) & 39.2 & & & 41 & \\
\hline Hemoglobin & $13.5-17.6 / 13.7-16.8(\mathrm{~g} / \mathrm{dL})$ & 13.3 & & & 13.5 & \\
\hline White-cell- count & 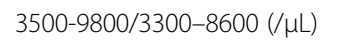 & 5300 & & & 5360 & \\
\hline Platelet count & $13.0-36.9 / 15.8-34.8\left(\times 10^{4} / \mu \mathrm{L}\right)$ & 9.8 & & & 12.2 & \\
\hline Albumin & 3.9-4.9/4.1-5.1 (g/dL) & 3.8 & & & 3.9 & \\
\hline Total Bilirubin & $0.2-1.2 / 0.4-1.5(\mathrm{mg} / \mathrm{dL})$ & 0.8 & & & 0.7 & \\
\hline AST & 8-38/13-30 (U/L) & 28 & & & 30 & \\
\hline ALT & 4-44/10-42 (U/L) & 13 & & & 16 & \\
\hline $\mathrm{LDH}$ & 106-211/124-222 (U/L) & 257 & & & 253 & \\
\hline ALP & 104-338/106-322 (U/L) & 226 & & & 250 & \\
\hline$\gamma$-GTP & 18-66/13-64 (U/L) & 20 & & & 21 & \\
\hline BUN & 8.0-20.0/8.0-20.0 (mg/dL) & 12.2 & & & 14.2 & \\
\hline Creatinine & $0.40-1.10 / 0.65-1.07(\mathrm{mg} / \mathrm{dL})$ & 0.57 & & & 0.58 & \\
\hline eGFR & $\left(\mathrm{mL} / \mathrm{min} / 1.73 \mathrm{~m}^{2}\right)$ & 128 & & & 98.7 & \\
\hline Sodium & 135-147/138-145 (mmol/L) & 141 & & & 142 & \\
\hline Potassium & 3.3-4.8/3.6-4.8 (mmol/L) & 3.3 & & & 3.9 & \\
\hline Chlor & 98-108/101-108 (mmol/L) & 108 & & & 105 & \\
\hline $\mathrm{HbA1c}$ & $5.0-6.2 / 4.9-6.0(\%)$ & 5.7 & & & 5.9 & \\
\hline Plasma glucose & 70-110/73-109 (mg/dL) & 44 & 47 & 40 & 147 & 57 \\
\hline Insulin & 1.09-17.02 /5.0-20.0 ( $\mu \mathrm{U} / \mathrm{mL})$ & 0.2 & & & & $<2.0$ \\
\hline C peptide & $0.8-2.5(\mathrm{ng} / \mathrm{mL})$ & & & & & $<0.2$ \\
\hline ACTH & 7.2-63.3/7.7-63.1 (pg/mL) & & 53.1 & & & \\
\hline Cortisol & $4.5-21.1 / 2-18(\mu \mathrm{g} / \mathrm{dL})$ & & 17.3 & & & 9 \\
\hline Growth hormone & $-2.47 /-3(\mathrm{ng} / \mathrm{mL})$ & & & 0.34 & & 4.2 \\
\hline Insulin growth factor 1 & $84-177^{\mathrm{a}}(\mathrm{ng} / \mathrm{mL})$ & & & 22 & & 21 \\
\hline Adrenalin & $-0.10 /-0.17(\mathrm{ng} / \mathrm{mL})$ & & & 0.11 & & 0.06 \\
\hline Noradrenalin & $0.10-0.50 / 0.15-0.57(\mathrm{ng} / \mathrm{mL})$ & & & 0.27 & & 0.26 \\
\hline Dopamine & $-0.03 /-0.03(\mathrm{ng} / \mathrm{mL})$ & & & $\leq 0.01$ & & $\leq 0.02$ \\
\hline Glucagon & $71-174 \mathrm{pg} / \mathrm{mL}(\mathrm{pg} / \mathrm{mL})$ & & & & & 154 \\
\hline Anti-insulin antibody & $-0.4(\%)$ & & $<0.4$ & & & \\
\hline
\end{tabular}

Glucagon and IGF1 were measured by radioimmunoassay (RIA); ACTH, cortisol, and growth hormone were measured by chemiluminescent enzyme immunoassay (CLEIA); adrenalin, noradrenalin, and dopamine were measured by High Performance Liquid Chromatography (HPLC)

a Reference range of Insulin growth factor 1 (IGF1) for 77 years old male. The reference range of IGF1 is differ by age and sex, only up to 77 years old

into pro-IGF2. Pro-IGF2 is processed into mature IGF2, which has a molecular weight of approximately $7.5 \mathrm{kDa}$. However, in most IGF2-producing NICTH, incomplete processing occurs, and one part of the $\mathrm{E}$ chain (C-terminal lesion of Pro-IGF2) remains; high molecular weight IGF2, or so-called big-IGF2 (molecular weight: $11-18 \mathrm{kDa}$ ) [10], is then detected in blood and tumors. Although the IHC stain for normal IGF2 of tumor is strong positive, a normal IGF2 was not detected in Western blotting in Fig. 4. A high molecular weight
IGF2, known as a big-IGF2 or pro-IGF-2E (68-88), contained same amino-acid sequence with normal IGF2 region, therefore it is impossible to distinguish large molecule IGF2 from normal IGF2 by IHC. Western blot analysis for tumor sample did not display normal IGF2 $(7.5 \mathrm{kDa})$ (if any, very tiny levels) but with very high levels of big IGF2, suggesting that majority of IGF2 produced in tumor is big-IGF2. The big-IGF2-IGF binding protein-3 (IGFBP-3) complex does not form a trimer with an acid labile subunit (ALS); therefore, it is easily 

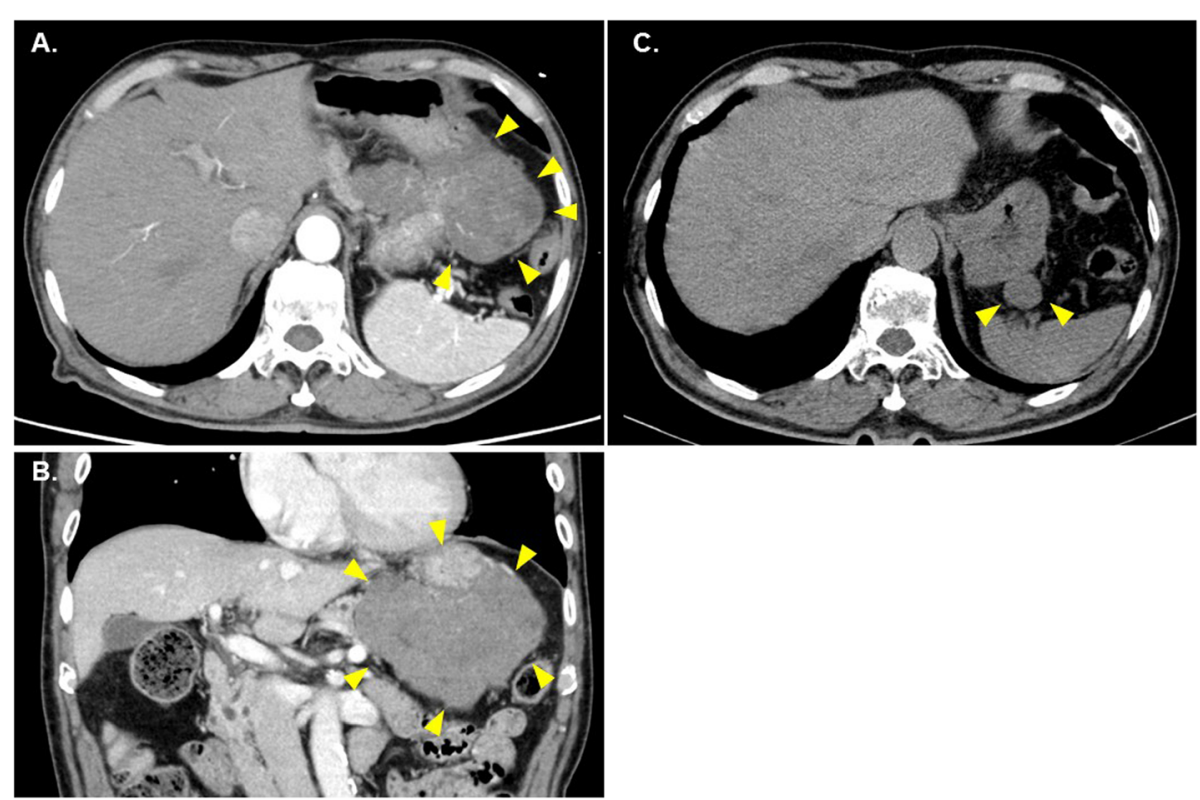

Fig. 1 CT scan of the abdomen. $\mathbf{a}$ and $\mathbf{b}$; at the time of admission. $\mathbf{c}$; one and a half years ago of admission

mobilized to the tissue where it exerts biological activity. Once the tumor was completely resected and hypoglycemia disappeared, such aberrant IGF2 disappeared from the blood, and the normal mature IGF2 level could increase [11]. In our case, $11-18 \mathrm{kDa}$ bigIGF2 was found in the serum and tissues before surgery by Western blot examination and disappeared after surgery. Tumors of $12 \mathrm{~cm}$ or greater were associated with significantly higher blood big-IGF2 concentrations [12]. Since IGF2 displays mitogen [3], the induction of IGF2 may contribute to the malignant transformation of GIST. Our case had a large tumor size of $12 \mathrm{~cm}$, the
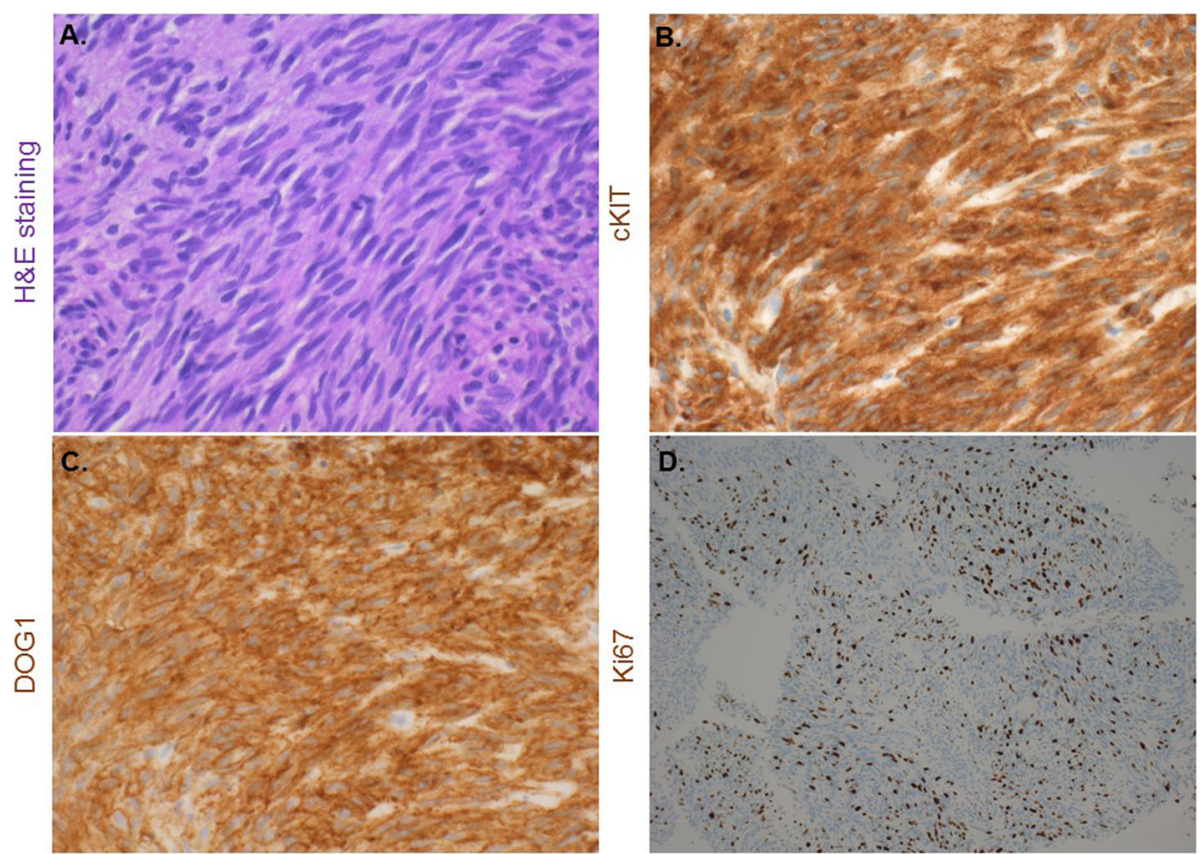

Fig. 2 Pathological findings of endoscopic ultrasound-guided fine-needle aspiration biopsy. a. Hematoxylin-eosin (HE) staining shows hyperplastic spindle cell. (X400). b. Immunostaining for c-KIT is diffuse positive in tumor cytoplasm. (X400). c. Immunostaining for Discovered on DOG-1 is diffuse strongly positive in tumor cytoplasm. (X400). d. Immunostaining for ki-67 is positive in nucleus. (X400) 


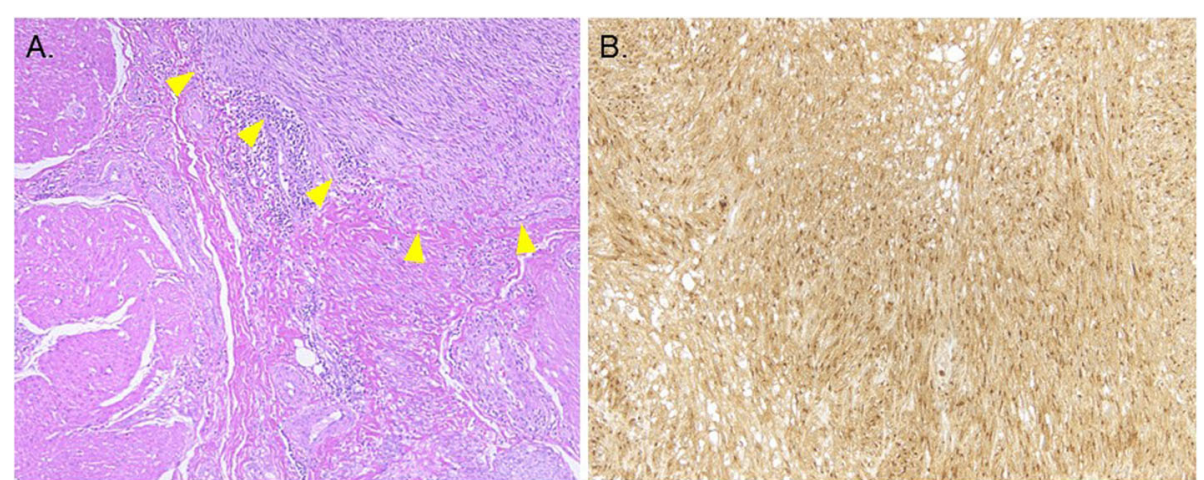

Fig. 3 Pathological findings of the resected specimen. a. Hematoxylin-eosin (HE) staining shows that tumor is primary muscular coat of gastric. (X100). b. Immunostaining for IGF2 is diffuse positive in tumor cytoplasm. (X100)

MIB-1 index was as high as 15.5\%, exhibiting characteristics of a high-risk tumor, and big-IGF2 could contribute to malignant transformation.

Most IGF2-producing tumors are large, and $70 \%$ are $\phi 10 \mathrm{~cm}$ or greater [13]. In our case, the tumor size was $\phi 12 \mathrm{~cm}$; the blood concentration of IGF2 was $722 \mathrm{ng} /$ $\mathrm{mL}$ and remained in the normal range (374-804). Regarding IGF2 concentration, only approximately $1 / 3$ of cases display high IGF2 blood levels in NICTH associated with IGF2-producing tumors [13]. Therefore, the IGF2/IGF1 ratio could be useful as a reference instead of the IGF2 value itself [14]. In our case, the preoperative IGF2/IGF1 ratio was as high as 33.6, consistent with an IGF2-producing tumor. One week after the operation, the IGF2/IGF1 ratio decreased but remained high, suggesting that the IGF1 level was not yet normalized. The reason why the restoration of IGF1 levels was not completed in our patients after operation was not clear yet. The big IGF2 is thought to suppress GH secretion and thereby reduces IGF1, therefore it could be possible that GH-IGF1 axis is not normalized yet at 1 week after operation. Also, we could not measure the levels of IGFBPs, by which IGFs levels and turn over were significantly modified [15]. Therefore, the potential contribution of IGFBPs level alteration before and after operation on the levels of IGF1 cannot be excluded. GIST is a common gastrointestinal mesenchymal tumor. The stomach is the most frequent site of GIST (39 to $72.3 \%$ [6] [7] [8]);

Table 2 IGF2 and IGF1 levels at pre and postoperative

\begin{tabular}{lll}
\hline & Pre operation & One week after operation \\
\hline IGF1 $(\mathrm{ng} / \mathrm{mL})$ & 21 & 39 \\
IGF2 $(\mathrm{ng} / \mathrm{mL})$ & 772 & 492 \\
IGF2/IGF1 & 33.6 & 12.6
\end{tabular}

IGF1 Insulin growth factor 1, IGF2 Insulin growth factor 2

Normal Range: IGF1 (84-177 ), IGF2 (374-804), IGF2/IGF1 (3.3-0.2)

a Normal range of IGF-1 for 77 years old man. The reference range of IGF1 is differ by age and sex, only up to 77 years old
IGF2-producing gastric GIST is rare [2]. Bodnar reported that 11 out of $288 \mathrm{NICTH}$ cases were caused by GIST. Furthermore, out of the 11 NICTH cases caused by GIST, only 1 case was associated with primary gastric GIST [2]. More frequent expression of big-IGF2 has been observed in moderate and higher risk tumors compared to tumors with a lower risk classification [16]. The level of big-IGF2 in gastric GIST has been shown to be relatively lower than that of the small intestine/colon [16], indicating the reason why a lower frequency of NICTH is associated with gastric GIST. The details by

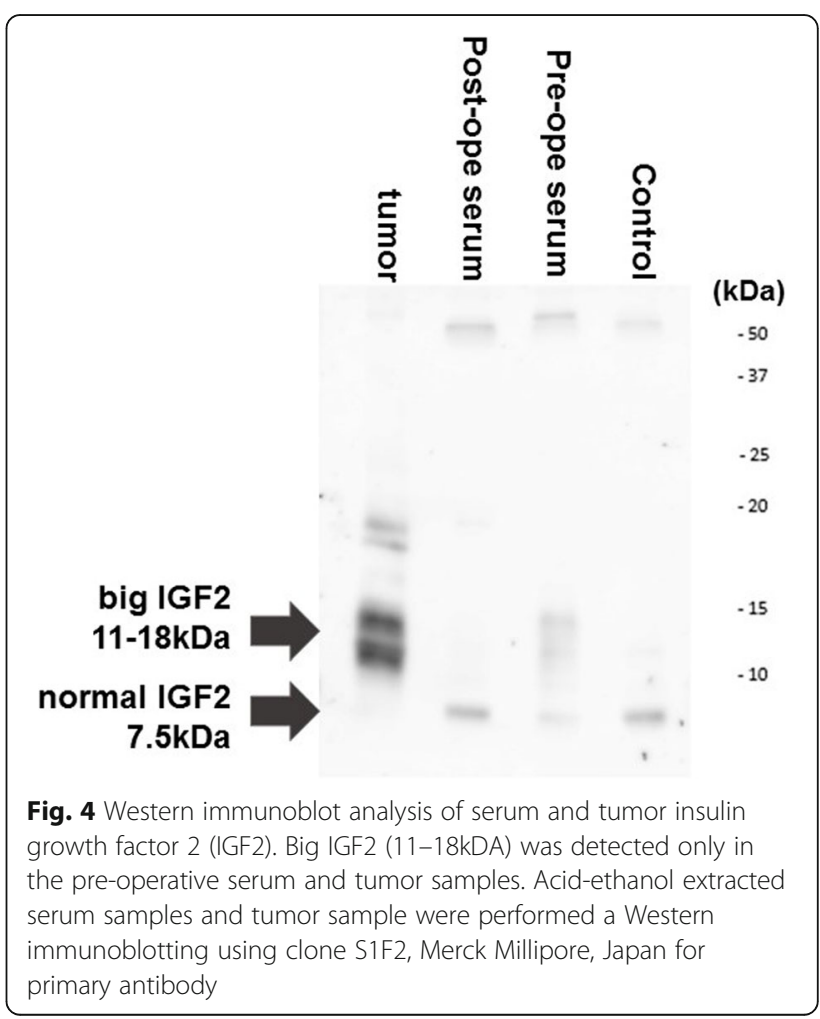


which lower big-IGF2 levels occur in gastric GISTs have not yet been elucidated, and further analysis is required.

In conclusion, we report a case of NICTH with IGF2producing primary gastric GIST. The frequency of NICTH associated with GIST of the stomach is rare; however, the large and high-risk GIST could produce big-IGF2 and subsequently cause severe hypoglycemia, requiring prompt evaluation, interpretation and complete tumor resection.

\section{Abbreviations}

NICTH: Non-islet cell tumor hypoglycemia; IGF: Insulin growth factor; GIST: Gastrointestinal stromal tumor; CT: Computed tomography; IPMN: Intraductal papillary mucinous neoplasm; ACTH: Adrenocorticotropic hormone; GH: Growth hormone

\section{Acknowledgements}

We thank the patient, his family and the medical staff who cared for him.

\section{Authors' contributions}

HY interpreted the patient's data and wrote the initial draft of the manuscript. Al conducted endoscopic ultrasound-guided fine-needle aspiration biopsy (EUS-FNA) and discussion from gastroenterologist point of view. MM interpreted the all patient's data and edited final manuscript. HM, M Yamamoto contributed in the patient care and data evaluation. HS supervised Al for EUS-FNA. ST, MN, M Yamauchi contributed to data collection, interpretation and discussion. YF operated the patient. NI performed the histological examination. IF conducted western blot analysis. SI and KK critically supervised the study and reviewed, intellectually interpreted, advised to generate the manuscript. All authors read and approved the final manuscript.

\section{Authors' information}

There is no conflict of interest in the study. KK is involved in the study at Division of Anticipatory Molecular Food Science and Technology, Medical Research Institute, Kanazawa Medical University, where Boehringer Ingelheim, Mitsubishi-Tanabe Pharma, Ono Pharma, Taisho Pharmaceutical, Kyowa Kirin contributed to establishing.

\section{Funding}

Not applicable.

\section{Availability of data and materials}

Not applicable.

\section{Ethics approval and consent to participate}

Not applicable.

\section{Consent for publication}

Written informed consent was obtained from the patient for publication of this case report and any accompanying images.

\section{Competing interests}

Not applicable.

\footnotetext{
Author details

'Department of Internal Medicine 1, Shimane University Faculty of Medicine, 89-1, Enya-cho, Izumo, Shimane 693-8501, Japan. ${ }^{2}$ Department of Internal Medicine 2, Shimane University Faculty of Medicine, 89-1, Enya-cho, Izumo, Shimane 693-8501, Japan. ${ }^{3}$ Department of Digestive and General Surgery, Shimane University Faculty of Medicine, 89-1, Enya-cho, Izumo, Shimane 693-8501, Japan. ${ }^{4}$ Department of surgical pathology, Shimane University Faculty of Medicine, 89-1, Enya-cho, Izumo, Shimane 693-8501, Japan. ${ }^{5}$ Division of diabetes, Endocrinology and Metabolism, Department of Medicine, Nippon Medical School, 1-1-15, sendagi, bunkyo-ku 113-8603, Japan. ${ }^{6}$ Division of Anticipatory Molecular Food Science and Technology, Medical Research Institute, Kanazawa Medical University, Uchinada, Ishikawa 920-0293, Japan.
}

Received: 27 December 2019 Accepted: 26 March 2020

Published online: 11 May 2020

\section{References}

1. Daughaday WH, Emanuele MA, Brooks MH, Barbato AL, Kapadia M, Rotwein P. Synthesis and secretion of insulin-like growth factor II by a leiomyosarcoma with associated hypoglycemia. N Engl J Med. 1988;319(22): 1434-40.

2. Bodnar TW, Acevedo MJ, Pietropaolo M. Management of non-islet-cell tumor hypoglycemia: a clinical review. J Clin Endocrinol Metab. 2014;99(3): $713-22$

3. Rikhof B, de Jong S, Suurmeijer AJ, Meijer C, van der Graaf WT. The insulinlike growth factor system and sarcomas. J Pathol. 2009;217(4):469-82.

4. Hirota S, Isozaki K, Moriyama Y, Hashimoto K, Nishida T, Ishiguro S, Kawano K. Hanada M, Kurata A, Takeda M, et al. Gain-of-function mutations of c-kit in human gastrointestinal stromal tumors. Science. 1998;279(5350):577-80.

5. Heinrich MC, Corless CL, Duensing A, McGreevey L, Chen CJ, Joseph N, Singer S, Griffith DJ, Haley A, Town A, et al. PDGFRA activating mutations in gastrointestinal stromal tumors. Science. 2003;299(5607):708-10.

6. Chan KH, Chan CW, Chow WH, Kwan WK, Kong CK, Mak KF, Leung MY, Lau LK. Gastrointestinal stromal tumors in a cohort of Chinese patients in Hong Kong. World J Gastroenterol. 2006;12(14):2223-8.

7. Kim KM, Kang DW, Moon WS, Park JB, Park CK, Sohn JH, Jeong JS, Cho MY, Jin SY, Choi JS, et al. Gastrointestinal stromal tumors in Koreans: it's incidence and the clinical, pathologic and immunohistochemical findings. J Korean Med Sci. 2005;20(6):977-84.

8. DeMatteo RP, Lewis JJ, Leung D, Mudan SS, Woodruff JM, Brennan MF. Two hundred gastrointestinal stromal tumors: recurrence patterns and prognostic factors for survival. Ann Surg. 2000;231(1):51-8.

9. Burvin R, LeRoith D, Harel H, Zloczower M, Marbach M, Karnieli E. The effect of acute insulin-like growth factor-ll administration on glucose metabolism in the rat. Growth Hormon IGF Res. 1998;8(3):205-10.

10. de Groot JW, Rikhof B, van Doorn J, Bilo HJ, Alleman MA, Honkoop AH, van der Graaf WT. Non-islet cell tumour-induced hypoglycaemia: a review of the literature including two new cases. Endocr Relat Cancer. 2007;14(4):979-93.

11. Fukuda I, Hizuka N, Takano K, Asakawa-Yasumoto K, Shizume K, Demura H. Characterization of insulin-like growth factor II (IGF-II) and IGF binding proteins in patients with non-islet-cell tumor hypoglycemia. Endocr J. 1993; 40(1):111-9.

12. Rikhof B, van Doorn J, Suurmeijer AJ, Rautenberg MW, Groenen PJ, Verdijk MA, Jager PL, de Jong S, Gietema JA, van der Graaf WT. Insulin-like growth factors and insulin-like growth factor-binding proteins in relation to disease status and incidence of hypoglycaemia in patients with a gastrointestinal stromal tumour. Ann Oncol. 2009;20(9):1582-8.

13. Fukuda I, Hizuka N, Ishikawa Y, Yasumoto K, Murakami Y, Sata A, Morita J, Kurimoto M, Okubo Y, Takano K. Clinical features of insulin-like growth factor-ll producing non-islet-cell tumor hypoglycemia. Growth Hormon IGF Res. 2006;16(4):211-6.

14. Hizuka N, Fukuda I, Takano K, Okubo Y, Asakawa-Yasumoto K, Demura H. Serum insulin-like growth factor II in 44 patients with non-islet cell tumor hypoglycemia. Endocr J. 1998;45(Suppl):S61-5.

15. Yakar S, Rosen CJ, Bouxsein ML, Sun H, Mejia W, Kawashima Y, Wu Y, Emerton K, Williams V, Jepsen K, et al. Serum complexes of insulin-like growth factor-1 modulate skeletal integrity and carbohydrate metabolism. FASEB J. 2009;23(3):709-19.

16. Rikhof B, van der Graaf WT, Suurmeijer AJ, van Doorn J, Meersma GJ, Groenen PJ, Schuuring EM, Meijer C, de Jong S. 'Big'-insulin-like growth factor-II signaling is an autocrine survival pathway in gastrointestinal stromal tumors. Am J Pathol. 2012;181(1):303-12.

\section{Publisher's Note}

Springer Nature remains neutral with regard to jurisdictional claims in published maps and institutional affiliations. 